\title{
Perlindungan Hak Kesehatan bagi Perempuan Sebagai Konsumen Pengguna Kosmetik Berdasarkan UU. No 8 Tahun 1999 Tentang Perlindungan Konsumen
}

\author{
Rezmia Febrina \\ Fakultas Hukum Universitas Lancang Kuning \\ Jl. Yos Sudarso Rumbai \\ E-mail: febrinarezmia@gmail.com
}

\begin{abstract}
The scope of human rights can not be separated from the protection of women because women in reality are often victims of violence. In every society and environment women's activities are often subjected to legal injustice or social intercourse. This situation is caused even worsened by the wrong perception in the family environment, society and state even though the cause and consequences of different context between each country, discrimination against women is felt to occur massively.

The type of this research is normative juridical research, that is a descriptive documentary study. This legal research is conducted by examining the literature or secondary data, also called bibliography legal research.

Protection of the right to health for women as consumer of cosmetic consumer based on Law No. 8 Year 1999 concerning consumer protection in Article 2 UUPK mentions consumer protection based on benefit, justice, balance, security, and consumer safety and legal certainty. In the explanation of Article 2 UUPK mentions consumer protection held as a joint venture. The Non-Governmental Organization for Consumer Protection protects the health rights of women using cosmetics based on Law No. 8/1999 on consumer protection in Article 44 of the Consumer Protection Law, explaining the existence of a Consumer Self-Help Protection Agency that helps women victims of drugs and cosmetics Dangerous, among others, the Government shall recognize a qualified non-governmental consumer protection agency. Non-governmental consumer protection agencies have the
\end{abstract}


opportunity to take an active role in realizing consumer protection.

In Article 19 of the Consumer Protection Act, it is realized that the producer as the business actor has responsibility to the consumer who uses the product that the business actor produces Education to the public regarding the legal protection for women as the consumer of the cosmetic user that has been regulated in Law No. 8/1999 on Consumer protection so that women as cosmetics consumers know the rights attached to him so that when using the cosmetics. Law enforcement provided by the government to cosmetics consumers especially women should be protected by the Consumers Protection of NGOs protecting the health rights of women using cosmetics based on Law No. 8 of 1999 on consumer Protection.

Keyword: Protection of Health Rights, User Based Cosmetics, Act. No. 8 of 1999.

\section{Abstrak}

Ruang lingkup HAM tidak terlepas dari perlindungan bagi perempuan karena perempuan dalam realitanya acapkali menjadi korban kekerasan. Dalam setiap masyarakat dan lingkungan kegiatan perempuan acapkali menjadi sasaran ketidakadilan hukum aupun pergaulan sosial. Keadaan ini di sebabkan bahkan diperburuk oleh adanya perepsi salah di lingkungan keluarga, masyarakat dan negara walupun sebab dan akibatnya berbeda konteksnya antara setiap negara, diskriasi terhadap perempuan dirasakan terjadi secara masif.

Jenis penelitian ini adalah penelitian yuridis normatif, yaitu suatu studi dokumenter yang bersifat deskriptif. Penelitian hukum ini dilakukan dengan cara meneliti bahan pustaka atau data sekunder belaka, yang disebut juga penelitian hukum kepustakaan.

Perlindungan hak kesehatan bagi perempuan sebagai konsumen pengguna kosmetik berdasarkan UU NO 8 Tahun 1999 tentang perlindungan konsumen dalam Pasal 2 UUPK menyebutkan Perlindungan konsumen berasaskan manfaat, keadilan, keseimbangan, keamanan, dan keselamatan 
konsumen serta kepastian hukum. Di dalam penjelasan Pasal 2 UUPK menyebutkan perlindungan konsumen diselenggarakan sebagai usaha bersama. Lembaga Perlindungan Konsumen Swadaya Masyarakat melindungi hak-hak kesehatan bagi perempuan pengguna kosmetik berdasarkan UU No 8 Tahun 1999 tentang perlindungan konsumen dalam pasal 44 Undang-Undang Perlindungan Konsumen di jelaskan adanya Lembaga perlindungan Konsumen Swadaya Masyarakat yang membantu perempuanperempuan korban obat-obatan dan kosmetik berbahaya antara lain Pemerintah mengakui lembaga perlindungan konsumen swadaya masyarakat yang memenuhi syarat. Lembaga perlindungan konsumen swadaya masyarakat memiliki kesempatan untuk berperan aktif dalam mewujudkan perlindungan konsumen.

Dalam pasal 19 Undang-Undang Perlindungan Konsumen dijelaksana bahwa produsen sebagai pelaku usaha memiliki tanggung jawab kepada konsumen yang menngunakan produk yang pelaku usaha hasilkan Edukasi kepada masyarakat mengenai perlindungan hukum bagi perempuan sebagai konsumen pengguna kosmetik yang sudah diatur dalam Undang-Undang No 8 Tahun 1999 tentang perlindungan konsumen sehingga perempuan sebagai konsumen kosmetik mengetahui hak yang melekat pada dirinya sehingga pada saat menggunakan kosmetik tersebut. Penegakkan hukum yang diberikan oleh pemerintah kepada konsumen kosmetik khususnya perempuan harus di lindungi oleh Lembaga Perlindungan Konsumen Swadaya Masyarakat melindungi hak-hak kesehatan bagi perempuan pengguna kosmetik berdasarkan UU No 8 Tahun 1999 tentang perlindungan konsumen.

Kata Kunci: Perlindungan Hak Kesehatan, Pengguna Kosmetik Berdasarkan, UU. No 8 Tahun 1999. 


\section{A. Pendahuluan}

\section{Latar Belakang}

Masyarakat internasional telah menyatakan secara eksplisit kebulatan tekadnya sebagaimana terangkum pada pasal 25 ayat (1) DUHAM yang menyatakan degan tegas :

"Setiap orang berhak atas taraf hidup yang menjamin kesehatan dan kesejahteraan untuk dirinya dan keluarganya termasuk pangan, pakaian, perumahan dan perawatan kesehatannya serta pelayanan sosial yag diperlukan dan berhak atas jamina pada saat menganggur, menderita sakit, cacat, dan menjadi janda mencapai usia lanjut atau mengalami kekurangan mata pencarian yang lain karena keadaan yang berada di luar kekuasaannya". ${ }^{1}$

Hak atas kesehatan dengan upaya minimalisasi dampak lingkungan bagi kehidupan masnusia. Ruang lingkup HAM atas kesehatan ditegaskan sebagai berikut " every human being has the rigth to an enverinment with minimum health risks and to have access to health services that can prevent or allaviate their suffering treat deseas and help maintain and promote good health troughout the individual's life ".2

Ruang lingkup HAM tidak terlepas dari perlindungan bagi perempuan karena perempuan dalam realitanya acapkali menjadi korban kekerasan. Dalam setiap masyarakat dan lingkungan kegiatan perempuan acapkali menjadi sasaran ketidakadilan hukum aupun pergaulan sosial. Keadaan ini di sebabkan bahkan diperburuk oleh adanya perepsi salah di lingkungan keluarga, masyarakat dan negara walupun sebab dan akibatnya berbeda konteksnya antara setiap negara, diskriasi terhadap perempuan dirasakan terjadi secara masif.

1 United Nation, Huan Rigth; A Compilation on International Instrumens, vol. 1 (Firts Part) (New York : United Nations, 2002), hlm. 5

${ }^{2}$ Katarina Tomasevki " Health Rigth" dalam Asborjn Eide et.al (ed) econimic, social dan cultural rigth ; A Texbook (Boston: artinus Nijhoff Publishers, 1995) hlm, 133 
Perlindungan konsumen adalah perangkat hukum yang diciptakan untuk melindungi dan terpenuhinya hak konsumen. ${ }^{3}$ Adapun tujuan perlindungan konsumen tersebut adalah sebagai berikut :

a. meningkatkan kesadaran, kemampuan dan kemandirian konsumen untuk melindungi diri;

b. mengangkat harkat dan martabat konsumen dengan cara menghindarkannya dari ekses negatif pemakaian barang dan/atau jasa;

c. meningkatkan pemberdayaan konsumen dalam memilih, menentukan dan menuntut hakhaknya sebagai konsumen

d. menciptakan sistem perlindungan konsumen yang mengandung unsur kepastian hokum dan keterbukaan informasi serta akses untuk mendapatkan informasi

e. menumbuhkan kesadaran pelaku usaha mengenai pentingnya perlindungan konsumen sehingga tumbuh sikap yang jujur dan bertanggung jawab dalam berusaha

f. meningkatkan kualitas barang dan/atau jasa yang menjamin kelangsungan usaha produksi barang dan/atau jasa, kesehatan, kenyamanan, keamanan, dan keselamatan konsumen.

Tetapi pada kenyataannya dalam undang-undang perlindungan konsumen ini tidak sepenuhnya hak-hak konsumen terpenuhi oleh undang-undang ini. Banyak sekali hak-hak konsumen yang di langgar baik di badan usaha yang berbadan hukum maupun yang tidak berbadan hukum contohnya saja perusahaan-perusahaan memproduksi obat dan kosmetik yang digunakan oleh masyarakat indonesia. Ada beberapa golongan obat dan kosmetik yang diproduksi oleh perusahaan-perudahaan yang banyak melakukan pelanggaran. Dimana obat dan kosmetik ini banyak di jual di

\footnotetext{
${ }^{3}$ Uu no 8 tahun 1999
} 
pasaran indonesia. Adapun obat-obat dan kosmetik yang di produksi oleh perusahaan-perusaan adalah sebagai berikut: ${ }^{4}$

a. Obat Bebas

Obat bebas adalah obat yang boleh digunakan tanpa resep dokter disebut obat OTC (Over The Counter), terdiri atas obat bebas dan obat bebas terbatas. Obat bebas dapat dijual bebas di warung kelontong, toko obat berizin, supermarket serta apotek.

b. Obat Bebas Terbatas

Obat bebas terbatas adalah obat yang sebenarnya termasuk obat keras tetapi masih dapat dijual atau dibeli bebas tanpa resep dokter, dan disertai dengan tanda peringatan. Tanda khusus pada kemasan dan etiket obat bebas terbatas adalah lingkaran biru dengan garis tepi berwarna hitam.

Seharusnya obat jenis ini hanya dapat dijual bebas di toko obat berizin (dipegang seorang asisten apoteker) serta apotek (yang hanya boleh beroperasi jika ada apoteker, no pharmacist no service), karena diharapkan pasien memperoleh informasi obat yang memadai saat membeli obat bebas terbatas.

c. Obat Wajib Apotek

OWA merupakan obat keras yang dapat diberikan oleh Apoteker Pengelola Apotek (APA) kepada pasien. Walaupun APA boleh memberikan obat keras, namun ada persayaratan yang harus dilakukan dalam penyerahan OWA.

1) Apoteker wajib melakukan pencatatan yang benar mengenai data pasien (nama, alamat, umur) serta penyakit yang diderita.

2) Apoteker wajib memenuhi ketentuan jenis dan jumlah yang boleh diberikan kepada pasien.

${ }^{4}$ http://damayantilinda.blogspot.com/2011/12/penggolongan-obatmenurut-uu-farmasi_08.html di akses pada tanggal 22 mei 2013 
Contohnya hanya jenis oksitetrasiklin salep saja yang termasuk OWA, dan hanya boleh diberikan 1 tube.

3) Apoteker wajib memberikan informasi obat secara benar mencakup: indikasi, kontra-indikasi, cara pemakain, cara penyimpanan dan efek samping obat yang mungkin timbul serta tindakan yang disarankan bila efek tidak dikehendaki tersebut timbul.

d. Obat Keras

Obat keras (dulu disebut obat daftar $\mathrm{G}=$ gevaarlijk $=$ berbahaya) yaitu obat berkhasiat keras yang untuk memperolehnya harus dengan resep dokter, berdasarkan keputusan Mentri Kesehatan RI Nomor 02396/A/SKA/III/1986 penandaan obat keras dengan lingkaran bulat berwarna merah dan garis tepi berwarna hitam serta huruf $\mathrm{K}$ yang menyentuh garis tepi. Obatobatan yang termasuk dalam golongan ini adalah antibiotik (tetrasiklin, penisilin, dan sebagainya), serta obat-obatan yang mengandung hormon (obat kencing manis, obat penenang, dan lain-lain). Obat-obat ini berkhasiat keras dan bila dipakai sembarangan bisa berbahaya bahkan meracuni tubuh, memperparah penyakit atau menyebabkan kematian. Obat-obat ini sama dengan narkoba yang kita kenal dapat menimbulkan ketagihan. Karena itu, obat-obat ini mulai dari pembuatannya sampai pemakaiannya diawasi dengan ketat oleh Pemerintah dan hanya boleh diserahkan oleh apotek atas resep dokter. Tiap bulan apotek wajib melaporkan pembelian dan pemakaiannya pada pemerintah.

e. Obat Psikotropika dan Narkotika.

Psikotropika adalah Zat/obat yang dapat menurunkan aktivitas otak atau merangsang susunan syaraf pusat dan menimbulkan kelainan perilaku, disertai dengan timbulnya halusinasi (mengkhayal), ilusi, gangguan cara 
berpikir, perubahan alam perasaan dan dapat menyebabkan ketergantungan serta mempunyai efek stimulasi (merangsang) bagi para pemakainya.

Narkotika adalah zat atau obat yang berasal dari tanaman atau bukan tanaman, baik sintetis maupun semi sintetis yang dapat menimbulkan pengaruh-pengaruh tertentu bagi mereka yang menggunakan dengan memasukkannya ke dalam tubuh manusia. Pengaruh tersebut berupa pembiusan, hilangnya rasa sakit, rangsangan semangat, halusinasi/timbulnya khayalankhayalan yang menyebabkan efek ketergantungan bagi pemakainya.

Dan kosmetik-kosmetik di produksi banyak yang berbahaya bagi kesehatan masayarakat khususnya bagi kesehatan wanita. Dimana kosmetik-kosmetik tersebut mengadung :

a. Merkuri, banyak disalahgunakan sebagai bahan pemutih/pencerah kulit, bersifat karsinogenik (menyebabkan kanker) dan teratogenik (mengakibatkan cacat pada janin).

b. Asam Retinoat, banyak disalahgunakan sebagai pengelupas kulit kimiawi (peeling), bersifat teratogenik.

c. Hidrokinon, banyak disalahgunakan sebagai bahan pemutih/pencerah kulit, selain dapat menyebabkan iritasi kulit, juga dapat menimbulkan ochronosis (kulit berwarna kehitaman) yang mulai terlihat setelah 6 bulan penggunaan dan kemungkinan bersifat irreversible (tidak dapat dipulihkan).

d. Bahan pewarna Merah K3 dan Merah K10, banyak disalahgunakan pada lipstik atau sediaan dekoratif lain (pemulas kelopak mata dan perona pipi). Kedua zat warna ini bersifat karsinogenik. ${ }^{5}$

5 http://solo.tribunnews.com/2016/09/28/inilah-43-produkkosmetik-berbahaya-menurut-bpom-2016-apakah-kosmetikmutermasuk?page $=2$ 
Perlindungan konsumen adalah perangkat yang diciptakan untuk melindungi dan terpenuhinya hak sebagai contoh para penjual diwajibkan menunjukka tanda harga sebagai tanda pemberitahuan kepada konsumen. Dengan kata lain, segala upaya yang menjamin adanya kepastian hukum untuk memberi perlindungan kepada konsumen. Di Indonesia, dasar hukum yang menjadikan seorang konsumen dapat mengajukan perlindungan adalah:

a. Undang Undang Dasar 1945 Pasal 5 ayat (1), pasal 21 ayat (1), Pasal 21 ayat (1), Pasal 27 , dan Pasal 33.

b. Undang Undang No. 8 Tahun 1999 Tentang Perlindungan Konsumen (Lembaran Negara Republik Indonesia tahun 1999 No. 42 Tambahan lembaran Negara Republik Indonesia No. 3821.

c. Undang Undang No. 5 tahun 1999 Tentang Larangan Praktek Monopoli dan Persaingan Usaha Usaha Tidak Sehat.

d. Undang Undang No. 30 Tahun 1999 Tentang Arbritase dan Alternatif Penyelesian Sengketa.

e. Peraturan Pemerintah No. 58 Tahun 2001 tentang Pembinaan Pengawasan dan Penyelenggaraan Perlindungan Konsumen.

f. Surat Edaran Dirjen Perdagangan Dalam Negeri No. 235/DJPDN/VII/2001 Tentang Penangan pengaduan konsumen yang ditujukan kepada Seluruh dinas Indag Prop/Kab/Kota.

g. Surat Edaran Direktur Jenderal Perdagangan Dalam Negeri No. 795 /DJPDN/SE/12/2005 tentang Pedoman Pelayanan Pengaduan Konsumen.

Menurut Undang- undang no.8 tahun 1999 tentang Perlindungan Konsumen Pasal 1 butir 1,2 dan 3:

a. Perlindungan Konsumen adalah segala upaya yang menjamin adanya kepastian hukum untuk memberi perlindungan kepada konsumen. 
b. Konsumen adalah setiap orang pemakai barang dan atau jasa yang tersedia dalam masyarakat, baik bagi kepentingan diri sendiri, keluarga, orang lain maupun makhluk hidup lain dan tidak untuk diperdagangkan

c. Pelaku usaha adalah setiap orang perseorangan taua badan usaha, baik yang berbentuk badan hukum maupun buka badan hukum yang didirikan dan berkedudukan atau melakukan kegiatan dalam wilayah hukum negara Republik Indonesia, baik sendiri maupun bersama- sama melalui perjanjian menyelenggaraka kegiatan usaha dalam berbagai bidang ekonomi.

Berdasarkan uraian dari latar belakang penulis menarik kesimpulan untuk mengangkat judul "Perlindungan Hak Kesehatan Bagi Perempuan Sebagai Konsumen Pengguna Kosmetik Berdasarkan Undang-Ndang No 8 Tahun 1999 Tentang Perlindungan Konsumen.”

\section{Rumusan Masalah}

Adapun yang menjadi rumusan permasalahan dalam penelitian ini adalah sebagai berikut:

a. Bagaimana perlindungan hak kesehatan bagi perempuan sebagai konsumen pengguna kosmetik berdasarkan UU NO 8 Tahun 1999 tentang Perlindungan Konsumen?

b. Bagaimana Lembaga Perlindungan Konsumen Swadaya Mayarakat melindungi hak-hak kesehatan bagi perempuan pengguna kosmmetik berdasarkan UU No 8 Tahun 1999 tentang Perlindungan Konsumen?

\section{Metode Penelitian}

Metode penelitian merupakan cara yang dilakukan untuk mencapai suatu tujuan. Sehubungan dengan itu, dalam penerapannya ditempuh langkah-langkah sebagai berikut:

\section{a. Jenis dan Sifat Penelitian}

Jenis penelitian ini adalah penelitian yuridis normatif, yaitu suatu studi dokumenter yang bersifat deskriptif. 
Penelitian hukum ini dilakukan dengan cara meneliti bahan pustaka atau data sekunder belaka, yang disebut juga penelitian hukum kepustakaan ${ }^{6}$.

Di dalam penelitian ini akan memfokuskan pada taraf sinkronisasi hukum secara horizontal. Di dalam penelitian terhadap taraf sinkronisasi, maka yang diteliti adalah sampai sejauh manakah hukum positif tertulis yang ada serasi.

Taraf sinkronisasi ditelaah dengan mengkaji perundangundangan suatu bidang kehidupan tertentu yang sederajat yang mengatur bidang yang sama. Penelitian ini dapat dilakukan secara lebih terperinci dengan membuat inventarisasi yang sejajar. Dengan menempatkan perundangundangan yang sederajat pada posisi yang sejajar, akan lebih mudah untuk mengadakan identifikasi terhadap taraf sinkronisasi nya yang rendah, sedang, atau tinggi.

\section{b. Sumber Data}

Penelitian hukum tidak mengenal adanya data untuk memecahkan isu hukum dan sekaligus memberikan preskripsi apa yang seharusnya diperlukan untuk sumbersumber penelitian. Data yang dikumpulkan dalam penelitian ini ialah data sekunder, antara lain mencakup dokumendokumen resmi, buku-buku, hasil-hasil penelitian yang berwujud laporan, buku harian, dan seterusnya.

Sumber-sumber penelitian hukum dapat dibedakan menjadi sumber-sumber penelitian yang berupa bahan hukum primer, sekunder, dan tersier.

1) Bahan hukum primer adalah bahan-bahan hukum yang mengikat dan terdiri dari:

a) Undang-Undang Dasar 1945;

b) Peraturan perundang-undangan dalam hal ini Undang-Undang No.30 Tahun 1999 tentang arbitrase dan alternatif penyelesaian sengketa,

${ }^{6}$ Soerjono Soekanto, Penelitian Hukum Normatif, Raja Grafindo Persada, Jakarta: 2003, hlm. 13. 
Lembaran Negara Republik Indonesia No.138 Tahun 1999;

c) Traktat yang berhubungan dengan arbitrase;

d) Yurisprudensi yang berhubungan dengan arbitrase;

e) Bahan hukum yang tidak dikodifikasikan, misalnya hukum adat.

2) Bahan hukum sekunder, yang memberi penjelasan mengenai bahan hukum primer misalnya, rancangan undang-undang, hasil-hasil penelitian tentang arbitrase, hasil karya dari kalangan hukum, dan seterusnya.

3) Bahan hukum tersier, yakni bahan yang memberikan petunjuk maupun penjelasan terhadap bahan hukum primer dan sekunder, misalnya kamus, ensiklopedia, indeks kumulatif, dan seterusnya. Metode dan alat pengumpulan bahan dilakukan melalui kegiatan studi pustaka.

\section{B. Kajian Teoritik}

Kerangka Teoritik adalah penggambaran antara konsepkonsep khusus yang merupakan dalam arti yang berkaitan dengan istilah yang akan diteliti dan/atau diuraikan dalam proposal.

\section{Perlindungan Konsumen}

Perlindungan konsumen adalah perangkat hukum yang diciptakan untuk melindungi dan terpenuhinya hak konsumen. ${ }^{7}$ Sebagai contoh, para penjual diwajibkan menunjukkan tanda harga sebagai tanda pemberitahuan kepada konsumen.

Dalam pasal 3 Undang-Undang Tentang Perlindungan Konsumen menjelaskan tentang tujuan dari perlindungan konsumen yaitu: ${ }^{8}$

\section{Konsumen}

${ }^{7}$ Undang - undang No. 8 tahun 1999 tentang Perlindungan

${ }^{8}$ ibid 
a. meningkatkan kesadaran, kemampuan dan kemandirian konsumen untuk melindungidiri;

b. mengangkat harkat dan martabat konsumen dengan cara menghindarkannya dari ekses negatif pemakaian barang dan/atau jasa;

c. meningkatkan pemberdayaan konsumen dalam memilih, menentukan dan menuntut hak-haknya sebagai konsumen;

d. menciptakan sistem perlindungan konsumen yang mengandung unsur kepastian hukum dan keterbukaan informasi serta akses untuk mendapatkan informasi;

e. menumbuhkan kesadaran pelaku usaha mengenai pentingnya perlindungan konsumen sehingga tumbuh sikap yang jujur dan bertanggung jawab dalam berusaha;

f. meningkatkan kualitas barang dan/atau jasa yang menjamin kelangsungan usaha produksi barang dan/atau jasa, kesehatan, kenyamanan, keamanan, dan keselamatan konsumen.

\section{Konsumen}

Bagi para ahli hukum pada umumnya sepakat bahwa arti konsumen adalah, pemakai terakhir dari benda dan jasa yang diserahkan kepada mereka oleh pengusaha. Dalam buku A.Z. Nasution yang berjudul aspek-aspek hukum masalah perlindungan konsumen, istilah konsumen berasal dari bahasa consumer (Inggris-Amerika) atau consument (Belanda). Secara harfiah arti kata consumer adalah lawan dari produsen, setiap orang yang menggunakan barang ${ }^{9}$

Konsumen yaitu setiap orang atau pembeli atas barang yang disepakati, menyangkut harga dan cara pembayarannya, tetapi tidak termasuk mereka yang mendapatkan barang untuk dijual kembali atau lain-lain keperluan komersial. bagi kepentingan diri sendiri, keluarga, orang lain, maupun

9 A.Z. Nasution, 2002, Hukum Perlindungan Konsumen, Diadit Media, Jakarta, hlm. 3 
mahluk hidup lain dan tidak untuk diperdagangkan. Selanjutnya untuk mempertegas makna dari barang dan/atau jasa yang dimaksudkan, UUPK juga memberikan definisi dari barang yaitu setiap benda, baik berwujud maupun tidak berwujud, baik bergerak maupun tidak bergerak, dapat dihabiskan maupun tidak dapat dihabiskan, yang dapat untuk diperdagangkan, dipakai, dipergunakan, atau dimanfaatkan oleh konsumen. Sedangkan jasa adalah setiap layanan yang berbentuk pekerjaan atau prestasi yang disediakan bagi masyarakat untuk dimanfaatkan oleh konsumen.

Menurut Shidarta, konsumen dapat juga diartikan setiap orang pemakai barang dan/jasa yang tersedia dalam masyarakat, baik bagi kepentingan diri sendiri, keluarga, orang lain maupun mahluk hidup lain dan tidak untuk diperdagangkan. Masyarakat umum mengartikan konsumen sebagai pembeli, penyewa, nasabah dari suatu lembaga jasa perbankan/asuransi, penumpang dari angkutan kota, pelanggan suatu perusahaan, dan masih banyak lagi lainnya.

Pengertian yang diberikan oleh masyarakat tersebut tidaklah salah sebab secara yuridis dalam hukum positif Indonesia terdapat subyek 12 Gunawan Widjaja. hukum yang dianggap sebagai konsumen. Dalam Kitab Undang-undang Hukum Perdata digunakan istilah pembeli (Pasal 1457 dst), penyewa (Pasal 1548 dst), peminjam pakai (Pasal 1470 dst) dan lain sebagainya. Semuanya memang dimaksudkan sebagai konsumen, pengguna barang dan jasa, namun tidak jelas apakah konsumen antara ataukah konsumen akhir.

Sesuai dengan ruang lingkup UUPK, menurut Shidarta ada 2 jenis konsumen diantaranya konsumen akhir (end consumer) yaitu setiap orang yang langsung mengkonsumsi barang dan atau jasa dan konsumen antara (intermediate consumer) yaitu setiap konsumen yang membeli suatu barang untuk kemudian dijual kembali kepada end consumer. UUPK hanya melindungi konsumen akhir sedangkan konsumen 
antara tidak dilindungi oleh UUPK karena telah diatur dalam peraturan-peraturan tentang perdagangan.

Berdasarkan pengertian 'konsumen' yang ada, maka secara umum konsumen dapat diartikan secara luas maupun sempit. Secara luas, konsumen mencakup semua pemakai barang dan atau jasa, yang berarti pengertian ini tidak dibatasi apakah penggunaan barang dan atau jasa tersebut hanya untuk memenuhi kebutuhannya atau untuk didistribusikan lagi kepada orang lain. Sedangkan secara sempit, pengertian konsumen mengacu pada konsumen akhir.

Lahirnya UUPK merupakan implementasi dari upaya untuk untuk melindungi kepentingan konsumen. Perlindungan hukum terhadap konsumen identik dengan perlindungan hukum terhadap hak-hak konsumen, artinya sebelum lahirnya UUPK kepentingan pelaku usaha dianggap lebih penting daripada hak-hak dan kepentingan konsumen serta jika terjadi penindasan terhadap hak-hak konsumen, untuk pemidanaannya tidak mempunyai dasar hukum yang kuat.

Adanya UUPK diharapkan dapat menjadi dasar hukum yang kuat dalam upaya pemerintah membenahi posisi konsumen yang selalu dilemahkan oleh pelaku usaha agar dapat berada di posisi yang sejajar dengan pelaku usaha.

Dalam usaha untuk membenahi posisi konsumen yang selama ini selalu dilemahkan oleh pelaku usaha, maka UUPK mengatur tentang hak dan kewajiban konsumen dan pelaku usaha.

Betapa pentingnya hak-hak konsumen, sehingga melahirkan pemikiran yang berpendapat bahwa hak-hak konsumen merupakan generasi keempat hak asasi manusia, yang merupakan kata kunci dalam konsepsi hak asasi manusia dalam perkembangan di masa yang akan datang. ${ }^{10}$

${ }^{10}$ Ahmad Miru dan Sutarman Yodo, 2004, Hukum Perlindungan Konsumen, (Yogyakarta , Raja Grafindo Persada), hlm. 180 
a. Hak dan Kewajiban Konsumen

Hak konsumen menurut Pasal 4 UUPK : ${ }^{11}$

1) Hak atas kenyamanan, keamanan, dan keselamatan dalam mengkonsumsi barang dan/atau jasa

2) Hak untuk memilih dan mendapatkan barang dan/atau jasa sesuai dengan nilai tukar dan kondisi serta jaminan yang dijanjikan

3) Hak atas informasi yang benar, jelas dan jujur mengenai kondisi dan jaminan barang dan/atau jasa

4) Hak untuk didengar pendapat dan keluhannya atas barang dan/atau jasa yang dipergunakan

5) Hak untuk mendapatkan advokasi, perlindungan, dan upaya penyelesaian sengketa perlindungan konsumen secara patut

6) Hak untuk mendapat pembinaan dan pendidikan konsumen

7) Hak untuk diperlakukan atau dilayani secara benar dan jujur serta tidak diskriminatif

8) Hak untuk mendapatkan kompensasi, ganti rugi dan/atau penggantian, apabila barang dan/atau jasa yang diterima tidak sebagaimana mestinya 9) Hakhak yang diatur dalam ketentuan peraturan perundang-undangan.

b. Kewajiban konsumen menurut Pasal 5 UUPK : ${ }^{12}$

1) Membaca atau mengikuti petunjuk informasi dan prosedur pemakaian atau pemanfaatan barang dan/atau jasa, demi keamanan dan keselamatan

2) Beritikad baik dalam melakukan transaksi pembelian barang dan/atau jasa

3) Membayar sesuai dengan nilai tukar yang disepakati

\footnotetext{
${ }^{11}$ Pasal 4 Undang - undang No. 8 tahun 1999 tentang Perlindungan Konsumen

12 Pasal 5 Undang - undang No. 8 tahun 1999 tentang Perlindungan Konsumen
} 
4) Mengikuti upaya penyelesaian hukum sengketa petlindungan konsumen secara patut

\section{Perlindungan Hak Kesehatan Bagi Perempuan Sebagai Konsumen Pengguna Kosmetik Berdasarkan UU NO 8 Tahun 1999 Tentang Perlindungan Konsumen}

Pasal 2 UUPK menyebutkan Perlindungan konsumen berasaskan manfaat, keadilan, keseimbangan, keamanan, dan keselamatan konsumen serta kepastian hukum. Di dalam penjelasan Pasal 2 UUPK menyebutkan perlindungan konsumen diselenggarakan sebagai usaha bersama berdasarkan 5 (lima) asas yang relevan dalam pembangunan nasional, yaitu:

a. Asas manfaat dimaksudkan untuk mengamanatkan bahwa segala upaya dalam penyelenggaraan perlindungan konsumen harus memberikan manfaat sebesar-besarnya bagi kepentingan konsumen dan pelaku usaha secara keseluruhan.

b. Asas keadilan dimaksudkan agar partisipasi seluruh rakyat dapat diwujudkan secara maksimal dan memberi kesempatan kepada konsumen dan pelaku usaha untuk memperoleh haknya dan melaksanakan kewajibannya secara adil.

c. Asas keseimbangan dimaksudkan untuk memberikan keseimbangan kepentingan konsumen, pelaku usaha dan pemerintah dalam arti materiil maupun secara spiritual.

d. Asas keamanan dan keselamatan konsumen dimaksudkan untuk memberikan jaminan atas keamanan dan keselamatan kepada konsumen dalam penggunaan, pemakaian, dan pemanfaatan barang dan/atau jasa yang dikonsumsi atau digunakan.

e. Asas kepastian hukum dimaksudkan agar baik pelaku usaha maupun konsumen menaati hukum dan memperoleh keadilan dalam penyelenggaraan 
perlindungan konsumen, serta negara menjamin kepastian hukum.

Dalam pasal 3 Undang-Undang Tentang Perlindungan Konsumen menjelaskan tentang tujuan dari perlindungan konsumen yaitu:

a. meningkatkan kesadaran, kemampuan dan kemandirian konsumen untuk melindungidiri

b. mengangkat harkat dan martabat konsumen dengan cara menghindarkannya dari ekses negatif pemakaian barang dan/atau jasa; meningkatkan pemberdayaan konsumen dalam memilih, menentukan dan menuntut hak-haknya sebagai konsumen;

c. menciptakan sistem perlindungan konsumen yang mengandung unsur kepastian hukum dan keterbukaan informasi serta akses untuk mendapatkan informasi;

d. menumbuhkan kesadaran pelaku usaha mengenai pentingnya perlindungan konsumen sehingga tumbuh sikap yang jujur dan bertanggung jawab dalam berusaha;

e. meningkatkan kualitas barang dan/atau jasa yang menjamin kelangsungan usaha produksi barang dan/atau jasa, kesehatan, kenyamanan, keamanan, dan keselamatan konsumen.

Bagi para ahli hukum pada umumnya sepakat bahwa arti konsumen adalah, pemakai terakhir dari benda dan jasa yang diserahkan kepada mereka oleh pengusaha. Dalam buku A.Z. Nasution yang berjudul aspek-aspek hukum masalah perlindungan konsumen, istilah konsumen berasal dari bahasa consumer (Inggris-Amerika) atau consument (Belanda). Secara harfiah arti kata consumer adalah lawan dari produsen, setiap orang yang menggunakan barang ${ }^{13}$

Konsumen yaitu setiap orang atau pembeli atas barang yang disepakati, menyangkut harga dan cara pembayarannya,

${ }^{13}$ A.Z. Nasution, Hukum Perlindungan Konsumen, (Jakarta, Diadit Media, 2002), hlm. 3 
tetapi tidak termasuk mereka yang mendapatkan barang untuk dijual kembali atau lain-lain keperluan komersial. bagi kepentingan diri sendiri, keluarga, orang lain, maupun mahluk hidup lain dan tidak untuk diperdagangkan. Selanjutnya untuk mempertegas makna dari barang dan/atau jasa yang dimaksudkan, UUPK juga memberikan definisi dari barang yaitu setiap benda, baik berwujud maupun tidak berwujud, baik bergerak maupun tidak bergerak, dapat dihabiskan maupun tidak dapat dihabiskan, yang dapat untuk diperdagangkan, dipakai, dipergunakan, atau dimanfaatkan oleh konsumen. Sedangkan jasa adalah setiap layanan yang berbentuk pekerjaan atau prestasi yang disediakan bagi masyarakat untuk dimanfaatkan oleh konsumen.

Betapa pentingnya hak-hak konsumen, sehingga melahirkan pemikiran yang berpendapat bahwa hak-hak konsumen merupakan generasi keempat hak asasi manusia, yang merupakan kata kunci dalam konsepsi hak asasi manusia dalam perkembangan di masa yang akan datang. ${ }^{14}$

\section{a. Hak dan Kewajiban Konsumen}

Hak konsumen menurut Pasal 4 UUPK : ${ }^{15}$

a. Hak atas kenyamanan, keamanan, dan keselamatan dalam mengkonsumsi barang dan/atau jasa

b. Hak untuk memilih dan mendapatkan barang dan/atau jasa sesuai dengan nilai tukar dan kondisi serta jaminan yang dijanjikan

c. Hak atas informasi yang benar, jelas dan jujur mengenai kondisi dan jaminan barang dan/atau jasa

d. Hak untuk didengar pendapat dan keluhannya atas barang dan/atau jasa yang dipergunakan

14 Ahmad Miru dan Sutarman Yodo, Hukum Perlindungan Konsumen, (Raja Grafindo Persada, Yogyakarta, 2004), hlm. 180

${ }^{15}$ Pasal 4 Undang - undang No. 8 tahun 1999 tentang Perlindungan Konsumen 
e. Hak untuk mendapatkan advokasi, perlindungan, dan upaya penyelesaian sengketa perlindungan konsumen secara patut

f. Hak untuk mendapat pembinaan dan pendidikan konsumen

g. Hak untuk diperlakukan atau dilayani secara benar dan jujur serta tidak diskriminatif

h. Hak untuk mendapatkan kompensasi, ganti rugi dan/atau penggantian, apabila barang dan/atau jasa yang diterima tidak sebagaimana mestinya

i. Hak-hak yang diatur dalam ketentuan peraturan perundang-undangan.

\section{Hak Produsen (Pelaku Usaha/Wirausahawan)}

Seperti halnya konsumen, pelaku usaha juga memiliki hak dan kewajiban. Hak pelaku usaha sebagaimana diatur dalam Pasal 6 UUPK adalah:

a. Hak menerima pembayaran yang sesuai dengan kesepakatan mengenai kondisi dan nilai tukar barang dan/atau jasa yang diperdagangkan.

b. Hak untuk mendapat perlindungan hukum dari tindakan konsumen yang beritikad tidak baik.

c. Hak untuk melakukan pembelaan diri sepatutnya di dalam penyelesaian hukum sengketa konsumen.

d. Hak untuk rehabilitasi nama baik apabila terbukti secara hukum bahwa kerugian konsumen tidak diakibatkan oleh barang dan/atau jasa yang diperdagangkan.

e. Hak-hak yang diatur dalam ketentuan peraturan perundang-undangan lainnya.

\section{Kewajiban Produsen}

a. Beritikad baik dalam kegiatan usahanya

b. Memberikan informasi yang benar, jelas dan jujur mengenai kondisi dan jaminan barang dan/atau jasa serta 
memberikan penjelasan, penggunaan, perbaikan dan pemeliharaan

c. Memperlakukan atau melayani konsumen secara benar dan jujur serta tidak diskriminatif

d. Menjamin mutu barang dan/atau jasa yang diproduksi dan/atau diperdagangkan berdasarkan ketentuan standar mutu dan/atau jasa yang berlaku

e. Memberi kesempatan kepada konsumen untuk menguji dan/atau mencoba barang dan/atau jasa yang dibuat dan/atau yang diperdagangkan

f. Memberi kompensasi, ganti rugi, dan/atau penggantian atas kerugian akibat penggunaan, pemakaian dan pemanfaatan barang dan/atau jasa yang diperdagangkan.

g. Memberi kompensasi ganti rugi dan/atau penggantian bila barang dan/atau jasa yang diterima atau dimanfaatkan tidak sesuai dengan perjanjian.

Bila diperhatikan dengan seksama, tampak bahwa hak dan kewajiban pelaku usaha bertimbal balik dengan hak dan kewajiban konsumen. Ini berarti hak bagi konsumen adalah kewajiban yang harus dipenuhi oleh pelaku usaha. Demikian pula dengan kewajiban konsumen merupakan hak yang akan diterima pelaku usaha.

Bila dibandingkan dengan ketentuan umum di Kitab Undang-Undang Hukum Perdata, tampak bahwa pengaturan UUPK lebih spesifik. Karena di UUPK pelaku usaha selain harus melakukan kegiatan usaha dengan itikad baik, ia juga harus mampu menciptakan iklim usaha yang kondusif, tanpa persaingan yang curang antar pelaku usaha.

\section{Tanggung Jawab Produsen Terhadap Konsumen}

Dalam pasal 19 Undang-Undang Perlindungan Konsumen dijelaksana bahwa prouden sebagai pelaku usaha memiliki tanggung jawab kepada konsumen yang menngunakan produk yang pelaku usaha hasilkan antara lain: 
a. Pelaku usaha bertanggung jawab memberikan ganti rugi atas kerusakan, pencemaran, dan/atau kerugian konsumen akibat mengkonsumsi barang dan/atau jasa yang dihasilkan atau diperdagangkan.

b. Ganti rugi sebagaimana dimaksud pada ayat 1 dapat berupa pengembalian uang atau penggantian barang dan/atau jasa yang sejenis atau setara nilainya, atau perawatan kesehatan dan/atau pemberian santunan yang sesuai dengan ketentuan peraturan perundang-undangan yang berlaku.

c. Pemberian ganti rugi dilaksanakan dalam tenggang waktu 7 (tujuh) hari setelah tanggal transaksi.

d. Pemberian ganti rugi sebagaimana dimaksud pada ayat 1 dan ayat 2 tidak menghapuskan kemungkinan adanya tuntutan pidana berdasarkan pembuktian lebih lanjut mengenai adanya unsur kesalahan.

Ketentuan sebagaimana dimaksud pada ayat 1 dan ayat 2 tidak berlaku apabila pelaku usaha dapat membuktikan bahwa kesalahan tersebut merupakan kesalahan konsumen

\section{Lembaga Perlindungan Konsumen Swadaya Masyarakat Melindungi Hak-Hak Kesehatan Bagi Perempuan Pengguna Kosmetik Berdasarkan UU No 8 Tahun 1999 Tentang Perlindungan Konsumen}

Dalam persepektif ICESCR dinyatakan bahwa hak yang sama antara laki-laki dan perempuan untuk menikmati ekonomi, sosial, dan budaya yang meliputi hak untuk mencari nafkah dan memilih pekerjaan, hak untuk menikati kondisi kerja yang adil dan menguntungkan, hak untuk membentuk serikat dalam serikat pekerja, hak atas jaminan sosial dan asuransi sosial, hak untuk mendapatkan perlindungan khusus terhadap kehailan, hak untuk mendapatkan perilaku yang nondiskriminatif, hak atas standar tertinggi kesehatan, hak atas pendidikan, hak dalam artisipasi dalam kehidupan budaya, penikmata manfaat 
teknologi dan keajuan teknologi dan hak mendapat perlindungan atas karya dan budaya.

Hak perlindungan perempuan menemukan momentum ketika Majelis Umum PBB mengeluarkan Resolusi 34/180 tanggal 18 Desember 1979 tentang Convention on the Elimination Of All Form Of Discrimination againts Women (CEDAW) yang berlaku efektif sejak 3 September $1979^{16}$. Bagi masyarakat internasional konvensi ini merupakan langkah maju untuk meposisikan kaum perempuan dalam perlindungan dan peenuhan HAM. Untuk mendukung pelaksanaan CEDAW dibentuklah sebuah komite, comitee on the Eiminaton $O f$ Discrimination againts Woment pada tahun 1982. Selanjutnya untuk mendukung kopetensi dan kinerja komukasi komite maka pada tanggal 25 mei 2000, Majelis umum mengeluarkan Resolusi 54/263 tentang Optional Protocol to the Convention on the Eliination of All Forms of Discrimination againts Women yang berlaku efektof sejak 22 Deseber 2000.

Dengan adanya hak terhadap perempuan yang di lindungi secara internasional, maka secara kebijakan Nasional perlu adanya konsideransinya dalam UndangUndang yang dapat menyatakan dengan tegas bahwa segala warga negara bersamaaan kedudukannya didalam hukum dan pemerintahan sehingga segala bentuk diskriminasi terhadap perempuan harus dihapuskan karena tidak sesuai dengan Pancasila dan UUD 1945. Dengan adanya Pancasila dan UUD 19545 sehingga perlu adanya Undang-Undang sehingga perempuan memiliki perlindungan terhadap obat dan kosmetik yang beredar di pasaran. Tetapi masih banyak pelanggaran yang dilakukan oleh Perusahaan-perusahaan

${ }^{16}$ C. De Rover, To Serve and to proteck ; human Rigths and Humanitarian Law for Police and Security Forces, Edisi Indonesia To Serve and to Proteck; acuan universal Penegakkan Huku ( Jakarta: PT Rjagravfindo Persada, 2000) hal 344 
yang memproduksi obat-obatan dan kosmetik yang dilarang sehingga diperlukan adanya Lembaga yang membantu perempuan-perempuan yang menjadi korban obata-obatan dan kosmetik berbahaya tersebut. Pada pasal 44 UndangUndang Perlindungan Konsumen di jelaskan adanya Lembaga perlindungan Konsumen Swadaya Masyarakat yang membantu perempuan-perempuan korban obat-obatan dan kosmetik berbahaya:

a. Pemerintah mengakui lembaga perlindungan konsumen swadaya masyarakat yang memenuhi syarat.

b. Lembaga perlindungan konsumen swadaya masyarakat memiliki kesempatan untuk berperan aktif dalam mewujudkan perlindungan konsumen.

c. Tugas lembaga perlindungan konsumen swadaya masyarakat meliputi kegiatan:

1) menyebarkan informasi dalam rangka meningkatkan kesadaran atas hak dan kewajiban dan kehatihatian konsumen dalam mengkonsumsi barang dan/atau jasa;

2) memberikan nasihat kepada konsumen yang memerlukannya;

3) bekerja sama dengan instansi terkait dalam upaya mewujudkan perlindungan konsumen;

4) membantu konsumen dalam memperjuangkan haknya, termasuk menerima keluhan atau pengaduan konsumen;

5) melakukan pengawasan bersama pemerintah dan masyarakat terhadap pelaksanaan perlindungan konsumen.

Ketentuan lebih lanjut mengenai tugas lembaga perlindungan konsumen swadaya masyarakat sebagaimana dimaksud pada ayat (3) diatur dalam Peraturan Pemerintah. ${ }^{17}$

${ }^{17}$ UU NO 8 TAHUN 1999 tentang Perlindungan Konsumen 
Pemerintah indonesia diharapkan memiliki komitmen yang cerdas dalam menggerakkan seluruh potensi anak bangsa tidak terkecuali para pembela HAM. ${ }^{18}$ Tentu saja sangkat dibutuhkan kesadaran dala kerjasama untuk pemenuhan HAM dengan dasar keterbukaan, jiwa besar dan tanggung jawab. Persepsi yang salah terhadap kehadiran HAM erupakan pangkal tolak dari lahirnya kecerobohan kebojakan yang engarah pada pendiskreditan citra pembela HAM di Indonesia.

Konsumen Menurut pengertian Pasal 1 angka 2 UU PK, "Konsumen adalah setiap orang pemakai barang dan/atau jasa yang tersedia dalam masyarakat, baik bagi kepentingan diri sendiri, keluarga, orang lain, maupun makhluk hidup lain dan tidak untuk diperdagangkan."

Pengertian Konsumen menurut Philip Kotler (2000) dalam bukunya Prinsiples Of Marketing adalah semua individu dan rumah tangga yang membeli atau memperoleh barang atau jasa untuk dikonsumsi pribadi.Undang-Undang Nomor 8 Tahun 1999 tentang Perlindungan Konsumen tidak memberikan batasan apakah yang dimaksud dengan sengketa konsumen. Definisi "sengketa konsumen" dijumpai pada Peraturan Menteri Perindustrian dan Perdagangan yaitu Surat Keputusan Nomor: 350/MPP/Kep/12/2001 tanggal 10 Desember 2001, dimana yang dimaksud dengan sengketa konsumen adalah:

"sengketa antara pelaku usaha dengan konsumen yang menutut ganti rugi atas kerusakan, pencemaran dan atau yang menderita kerugian akibat mengkonsumsi barang atau memanfaatkan jasa."

Jadi, sengketa konsumen adalah sengketa antara pelaku usaha dengan konsumen yang menutut ganti rugi atas kerusakan, pencemaran dan atau yang menderita kerugian

18 Pidato Pebukaan Komisi Tinggi HAM PBB pada Sidang terakhir Working Group on Huan Rigths Defenders, 23 Februari 1998 
akibat mengkonsumsi barang atau memanfaatkan jasad. Melalui pasal 45 ayat (1) ini dapat diketahui bahwa untuk menyelesaikan sengketa konsumen, terdapat dua pilihan yaitu melalui lembaga yang bertugas menyelesaikan sengketa antara konsumen dan pelaku usaha, atau melalui peradilan yang berada di lingkungan peradilan umum. Dalam UndangUndang no 8 Tahun 1998 di jelaskan pemerintah telah membentuk Badan Perlindungan Konsumen yang memiliki tgas untuk mengawasi dan mengembangakan perlindungan konsumen. Untuk menjalankan fungsi sebagaimana dimaksud dalam Pasal 33, Badan Perlindungan Konsumen Nasional mempunyai tugas:

a. memberikan saran dan rekomendasi kepada pemerintah dalam rangka penyusunan kebijaksanaan di bidang perlindungan konsumen;

b. melakukan penelitian dan pengkajian terhadap peraturan perundang-undangan yang berlaku di bidang perlindungan konsumen;

c. melakukan penelitian terhadap barang dan/at au jasa yang menyangkut keselamatan konsumen;

d. mendorong berkembangnya lembaga perlindungan konsumen swadaya masyarakat;

e. menyebarluaskan informasi melalui media mengenai perlindungan konsumen dan memasyarakatkan sikap keberpihakan kepada konsumen;

f. menerima pengaduan tentang perlindungan konsumen dari masyarakat, lembaga perlindungan konsumen swadaya masyarakat, atau pelaku usaha;

g. melakukan survei yang menyangkut kebutuhan konsumen

Dalam melaksanakan tugas sebagaimana dimaksud pada ayat (1), Badan Perlindungan Konsumen Nasional dapat bekerja sama dengan organisasi konsumen internasional.

Pemerintah mengakui lembaga perlindungan konsumen swadaya masyarakat yang memenuhi syarat. Lembaga 
perlindungan konsumen swadaya masyarakat memiliki kesempatan untuk berperan aktif dalam mewujudkan perlindungan konsumen. Tugas lembaga perlindungan konsumen swadaya masyarakat meliputi kegiatan:

a. menyebarkan informasi dalam rangka meningkatkan kesadaran atas hak dan kewajiban dan kehati-hatian konsumen dalam mengkonsumsi barang dan/atau jasa;

b. memberikan nasihat kepada konsumen yang memerlukannya;

c. bekerja sama dengan instansi terkait dalam upaya mewujudkan perlindungan konsumen;

d. membantu konsumen dalam memperjuangkan haknya, termasuk menerima keluhan atau pengaduan konsumen;

e. melakukan pengawasan bersama pemerintah dan masyarakat terhadap pelaksanaan perlindungan konsumen.

Ketentuan lebih lanjut mengenai tugas lembaga perlindungan konsumen swadaya masyarakat sebagaimana dimaksud pada ayat (3) diatur dalam Peraturan Pemerintah.

\section{E. Kesimpulan}

1. Dalam pasal 19 Undang-Undang Perlindungan Konsumen dijelaksana bahwa produsen sebagai pelaku usaha memiliki tanggung jawab kepada konsumen yang menngunakan produk yang pelaku usaha hasilkan antara lain:

a. Pelaku usaha bertanggung jawab memberikan ganti rugi atas kerusakan, pencemaran, dan/atau kerugian konsumen akibat mengkonsumsi barang dan/atau jasa yang dihasilkan atau diperdagangkan.

b. Ganti rugi sebagaimana dimaksud pada ayat 1 dapat berupa pengembalian uang atau penggantian barang dan/atau jasa yang sejenis atau setara nilainya, atau perawatan kesehatan dan/atau pemberian santunan yang 
sesuai dengan ketentuan peraturan perundang-undangan yang berlaku.

c. Pemberian ganti rugi dilaksanakan dalam tenggang waktu 7 (tujuh) hari setelah tanggal transaksi.

d. Pemberian ganti rugi sebagaimana dimaksud pada ayat 1 dan ayat 2 tidak menghapuskan kemungkinan adanya tuntutan pidana berdasarkan pembuktian lebih lanjut mengenai adanya unsur kesalahan.

2. Pemerintah mengakui lembaga perlindungan konsumen swadaya masyarakat yang memenuhi syarat. Lembaga perlindungan konsumen swadaya masyarakat memiliki kesempatan untuk berperan aktif dalam mewujudkan perlindungan konsumen. Tugas lembaga perlindungan konsumen swadaya masyarakat meliputi kegiatan:

a. Menyebarkan informasi dalam rangka meningkatkan kesadaran atas hak dan kewajiban dan kehati-hatian konsumen dalam mengkonsumsi barang dan/atau jasa

b. Memberikan nasihat kepada konsumen yang memerlukannya;

c. Bekerja sama dengan instansi terkait dalam upaya mewujudkan perlindungan konsumen;

d. Membantu konsumen dalam memperjuangkan haknya, termasuk menerima keluhan atau pengaduan konsumen;

e. Melakukan pengawasan bersama pemerintah dan masyarakat terhadap pelaksanaan perlindungan konsumen

Ketentuan lebih lanjut mengenai tugas lembaga perlindungan konsumen swadaya masyarakat sebagaimana dimaksud pada ayat (3) diatur dalam Peraturan Pemerintah. 


\section{Daftar Pustaka}

\section{Buku}

A.Z. Nasution, Jakarta, Hukum Perlindungan Konsumen, Diadit Media, 2002

Ahmad Miru dan Sutarman Yodo, 2004, Hukum Perlindungan Konsumen, Raja Grafindo Persada, Yogyakarta

C. De Rover, To Serve and to proteck ; human Rigths and Humanitarian Law for Police and Security Forces, Edisi Indonesia To Serve and to Proteck; acuan universal Penegakkan Huku ( Jakarta: PT Rjagravfindo Persada, 2000) hal 344

Katarina Tomasevki “ Health Rigth" dalam Asborjn Eide et.al (ed) econimic, social dan cultural rigth ; A Texbook (Boston: artinus Nijhoff Publishers, 1995) Pidato Pebukaan Komisi Tinggi HAM PBB pada Sidang terakhir Working Group on Huan Rigths Defenders, 23 Februari 1998

United Nation, Huan Rigth; A Compilation on International Instrumens, vol. 1 (Firts Part) (New York : United Nations, 2002)

\section{Undang-Undang}

Undang - undang No. 8 tahun 1999 tentang Perlindungan Konsumen

\section{Internet}

http://damayantilinda.blogspot.com/2011/12/penggolongan-

obat-menurut-uu-farmasi_08.html di akses pada tanggal 22 mei 2013

http://solo.tribunnews.com/2016/09/28/inilah-43-produk-

kosmetik-berbahaya-menurut-bpom-2016-apakahkosmetikmu-termasuk?page $=2$ 
202 Rezmia Febrina: Perlindungan Hak Kesehatan Bagi....

Fikri, Vol. 2, No. 1, Juni 2017

P-ISSN: 2527- 4430

E-ISSN: 2548-7620 